THE RENAISSANCE 


\section{Studies in European History}

\begin{tabular}{|c|c|}
\hline Series Editors: & $\begin{array}{l}\text { John Breuilly } \\
\text { Julian Jackson } \\
\text { Peter Wilson }\end{array}$ \\
\hline Jeremy Black & A Military Revolution? Military Change and European \\
\hline T.C.W. Blanning & $\begin{array}{l}\text { Society, } 1550-1800 \\
\text { The French Revolution: Class War or Culture Clash? }\end{array}$ \\
\hline & (2nd edn) \\
\hline John Breuilly & The Formation of the First German Nation-State, $1800-1871$ \\
\hline Peter Burke & The Renaissance (2nd edn) \\
\hline $\begin{array}{l}\text { Michael L. Dockrill } \\
\text { and }\end{array}$ & \\
\hline Michael F. Hopkins & The Cold War 1945-1991 (2nd edn) \\
\hline William Doyle & The Ancien Régime (2nd edn) \\
\hline William Doyle & Jansenism \\
\hline Andy Durgan & The Spanish Civil War \\
\hline Geoffrey Ëllis & The Napoleonic Empire (2nd edn) \\
\hline Donald A. Filtzer & The Krushchev Era \\
\hline Mary Fulbrook & $\begin{array}{l}\text { Interpretations of the Two Germanies, } 1945-1990 \\
\text { (2nd edn) }\end{array}$ \\
\hline Graer & Stalinism (2nd edn) \\
\hline Hugh Gough & The Terror in the French Revolution \\
\hline John & $\begin{array}{l}\text { The Scientific Revolution and the Origins of Modem Science } \\
\text { (3rd edn) }\end{array}$ \\
\hline efan-Ludwig & \\
\hline Hoffmann & Civil Society, 1750-1914 \\
\hline Henry Kamen & Golden Age Spai \\
\hline Richard Mackenney & The City-State, $1500-1700$ \\
\hline $\begin{array}{l}\text { Andrew Porter } \\
\text { Roy Porter }\end{array}$ & $\begin{array}{l}\text { European Imperialism, 1860-1914 } \\
\text { The Enlightenment (2nd edn) }\end{array}$ \\
\hline $\begin{array}{l}\text { Roger Price } \\
\text { lames Retallack }\end{array}$ & $\begin{array}{l}\text { The Revolutions of } 1848 \\
\text { Germany in the Age of Kaiser Wilhelm II }\end{array}$ \\
\hline $\begin{array}{l}\text { Geoffrey Scarre } \\
\text { and John Callan }\end{array}$ & $\begin{array}{l}\text { Germany in the Age of Kaiser Wilhelm II } \\
\text { Witchcraft and Magic in 16th-and 17th-Century } \\
\text { Europe (2nd edn) }\end{array}$ \\
\hline $\begin{array}{l}\text { R.W. Scribner and } \\
\text { C. Scott Dixon }\end{array}$ & The German Reformation (2nd edn) \\
\hline $\begin{array}{l}\text { Robert Service } \\
\text { Jeremv Smith }\end{array}$ & The Russian Revolution, 1900-1927 (3rd edn) \\
\hline David Stevenson & The Outbreak of the First World War \\
\hline ter H. Wilson & The Holy Roman Empire, 1495-1806 \\
\hline liver Zimmer & Nationalism in Europe, 1890-1940 \\
\hline
\end{tabular}

\section{Studies in European History \\ Series Standing Order ISBN 0-333-79365-X \\ (outside North America only)}

You can receive future titles in this series as they are published by placing a standing order. Please contact your bookseller or, in case of difficulty, write to us at the address below with your name and address, the title of the series and the ISBN quoted above.

Customer Services Department, Macmillan Distribution Ltd Houndmills, Basingstoke, Hampshire RG21 6XS, England 


\title{
THE RENAISSANCE
}

\section{Second Edition}

\author{
PETER BURKE
}

Professor of Cultural History

University of Cambridge 


\section{Published in Great Britain by}

\section{MACMILLAN PRESS LTD}

Houndmills, Basingstoke, Hampshire RG21 6XS and London

Companies and representatives throughout the world

A catalogue record for this book is available from the British Library.

ISBN 978-0-333-66927-3 ISBN 978-1-349-25495-8 (eBook)

DOI 10.1007/978-1-349-25495-8

Published in the United States of America by

ST. MARTIN'S PRESS, INC.,

Scholarly and Reference Division,

175 Fifth Avenue, New York, N.Y. 10010

ISBN 978-0-312-17230-5

Library of Congress Cataloging-in-Publication Data

Burke, Peter.

The Renaissance / Peter Burke. - 2nd ed.

p. $\mathrm{cm}$. - (Studies in European history)

Includes bibliographical references and index.

ISBN 978-0-312-17230-5 (pbk.)

1. Renaissance. I. Title. II. Series: Studies in European

history (New York, N.Y.)

CB361.B8 1997

$940.2^{\prime} 1-\mathrm{dc} 20$

96-43456

CIP

(ㄷ) Peter Burke 1987, 1997

First edition 1987

Reprinted 1989, 1990, 1992, 1993, 1994, 1995

Second edition 1997

All rights reserved. No reproduction, copy or transmission of this publication may be made without written permission.

No paragraph of this publication may be reproduced, copied or transmitted save with written permission or in accordance with the provisions of the Copyright, Designs and Patents Act 1988, or under the terms of any licence permitting limited copying issued by the Copyright Licensing Agency, 90 Tottenham Court Road, London WIP 9HE.

Any person who does any unauthorised act in relation to this publication may be liable to criminal prosecution and civil claims for damages.

The author has asserted his rights to be identified as the author of this work in accordance with the Copyright, Designs and Patents Act 1988.

This book is printed on paper suitable for recycling and made from fully managed and sustained forest sources. Logging, pulping and manufacturing processes are expected to conform to the environmental regulations of the country of origin. 


\section{Contents}

List of Plates

Editor's Preface

1 The Myth of the Renaissance

2 Italy: Revival and Innovation

3 The Renaissance Abroad: or the Uses of Italy

vi

4 The Disintegration of the Renaissance

5 Conclusion

Select Bibliography

Index 


\section{List of Plates}

1 Self-portrait of Martin van Heemskerck (courtesy of the Fitzwilliam Museum, Cambridge)

2 Bramantes Tempietto (courtesy of the Mansell Collection)

3 Botticellis Calumny (courtesy of the Mansell Collection)

4 Michelangelos Bacchus (courtesy of the Mansell Collection)

5 The Pantheon in Rome (courtcsy of the Mansell Collection)

6 Diagram from Bouelles, De Sapiente (courtesy of the British Library) 


\section{Editor's Preface}

The main purpose of this new series of Macmillan studies is to make available to teacher and student alike developments in a field of history that has become increasingly specialised with the sheer volume of new research and literature now produced. These studies are designed to present the 'state of the debate' on important themes and episodes in European history since the sixteenth century, presented in a clear and critical way by someone who is closely concerned himself with the debate in question.

The studies are not intended to be read as extended bibliographical essays, though each will contain a detailed guide to further reading which will lead students and the general reader quickly to key publications. Each book carries its own interpretation and conclusions, while locating the discussion firmly in the centre of the current issues as historians see them. It is intended that the series will introduce students to historical approaches which are in some cases very new and which, in the normal course of things, would take many years to filter down into textbooks and school histories. I hope it will demonstrate some of the excitement historians, like scientists, feel as they work away in the vanguard of their subject.

The format of the series conforms closely with that of the companion series of studies in economic and social history, which has already established a major reputation since its inception in 1968. Both series have an important contribution to make in publicising what it is that historians are doing and in making history more open and accessible. It is vital for history to communicate if it is to survive.

\section{R. J. OVERY}

